\title{
水質保全の問題点と対策
}

太田耕 生*

\section{A. まえがき}

水は昔加清澄なるもの, 無尽藏なものとしてわれわ れのイメージの中に固定していた. 山紫水明, 明鏡止水 なる言葉が人口に膾多されていた所以である．昭和 20 年 代までは全国至るところの海, 湖や河川で泳げたし，魚 を追うこともできた．河も少しばかり上流に遡ると底ま ですき透った清洌な水が得られ，小魚の泳ぐのが手に之 るようにみえた。海もしかりで文字通り白砂青松の浜辺 が拡がり, 近海の魚は美味あのの代名詞であった。

水は水産物の生育のためばかりでなく, 農業用水, 発 電用水，工業用水，家庭用水として不可欠のあのである が，中でも近年工業化の進展とともに工業用水の需要の 伸びがいちじるしい，昭和 35 年当時の池田内閣の所得倍 増計画の提唱, 引続いて37年全国総合開発計画による拠 点開発方式の企画立案, 新産業都市の指定, さらに39年 工業整備特別地域の指定など一連の重化学工業化施策が 遂行され, 国際競争力の強化, 輸出振興運動が行われ た.この結果今日の GNP 大国を築き上げることができ たが，反面，過密工業化社会を現出し公害問題が全国的 飞紛争の種となった．われわれの所得が增へ，物質文明 の利益を享受できるようになった裹面では河川，湖沼， 海域, ところ選ばず污濁し, 水銀, PCB 污染魚や油臭 魚が発生するようになった．わが国の工業集積度は表 1 にみるごとくアメリカ，イギリスと比較すると格段の高 さを示している.

表 1 日本の対外国平地面積当りの指標（1970年）

\begin{tabular}{|c|c|c|c|}
\hline & G N P & 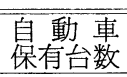 & $\begin{array}{l}\text { Iネルギ一 } \\
\text { 消 費 量 }\end{array}$ \\
\hline 対アメリカ & 11.3倍 & 9 倍 & 6.9倍 \\
\hline 対イギリス & 3.2 倍 & 2.5倍 & 1.8倍 \\
\hline
\end{tabular}

このような高密度社会から排出された污濁物質が，ま ったくもしくは十分処理されることなく環境に放出され たし，また社会すこの行為を許容してきた. 工場および 家庭からでる污水は一旦公共用水域すなわち河川, 海に 排出されると実際上処理が不可能になる．排出される前

* 環境庁 水質保全局水質規制課長
は濃度む濃く水量む少なく，さらに非出者はその成分を 熟知しているので処理が簡単であるが，数年前まではこ れに対する関心がなかった。

そしててのようにして污水を排出するてとによって社 会に与えたマイナスの効果に対し，排出者はまったく費 用を負担する必要がなかった。すなわち市場欠落であ る。したがって日本の産業は社会に外部負経済を与えな がら世界でもっとも安くて, 性能のよい工業製品を供給 してきた．そして外貨準備が增加し，円が強くなり実質 的に 2 度にわたる円切上げを招来し, 日本品の急激な進 出が外国市場での摩擦を生じさせたてとは記憶に 新し い. 私どあの美しい自然は思い屯よら始破壊され，污 でされてしまっている. そして現にそれが一部では進行 している．埋立を例にとるならば瀬戸内海ですでに埋立 てられたかまたは工事中のものは 2.4 億 $\mathrm{m}^{2}$ に達し，同 内海第 2 の島小豆島の 1.5 倍に達している.

この結果広島, 岡山, 香川の 3 県での海婩線の改変 状況は表 2 のとおりで昭和 45 年における人工の海岸汀線 は内陸側で50〜70\%に達している. そして純自然の状態 のあのは 8〜27\%と減少している. ての埋立が主として 工業用地を供給してきた。埋立られるところは底まで日 光が差し込み, 魚が産卵し稚魚が成育し, 海澡が繁茂す る浅瀬，砂浜である.すなわち自然の浄化作用が働く之 ころである. このような白砂青松の場所に工場が立てら れ，そこから污水が流出した。 そして自然の景観を破壊 し, 水浴場を奪い, 美味しい近海の魚を污染した. 工業 化することにより地域経済が発展し，そこに住む住民む この恩恵を蒙ることができるだろうとの期待感があり， 昭和30年代の工業開発は比較的スムーズに受け入れられ たが，乙の期待はかなえられなかったケースが多い.

岡山県水島臨海工業地带における地区住民の生活意識 調査によれば生活がよくなったとするもの $4.6 \%$ に対し 悪くなったとするすのが70\%以上に達している.

水俣病, イタイイタイ病, 昨年火を吹いた形の PCBや 水銀污染魚の全国的昖がり，各地にみられる魚の弊死や 奇形魚騒ぎなどは呼吸病患者をむたらした大気污染とと あに公害に対する住民運動を激化させるとともに開発拒 
表 2 瀬戸内海沿岸地域海岸丁線改変表

(単位:\%)

\begin{tabular}{|c|c|c|c|c|c|c|c|c|c|c|c|}
\hline \multirow{2}{*}{ 県 } & \multirow{2}{*}{\multicolumn{2}{|c|}{ 别 }} & \multirow{2}{*}{ 地 } & \multirow{2}{*}{ 域 } & \multirow{2}{*}{ 別 } & \multicolumn{2}{|c|}{ 純自然海岸汀線 } & \multicolumn{2}{|c|}{ 半自然海岸汀線 } & \multicolumn{2}{|c|}{ 人工海岸汀線 } \\
\hline & & & & & & 30 年 & 45年 & 30年 & 45年 & 30年 & 45年 \\
\hline \multirow{2}{*}{ 広 } & \multirow{2}{*}{ 島 } & \multirow{2}{*}{ 県 } & 山 & 陽 & 側 & 21.0 & 8.0 & 43.4 & 22.5 & 35.6 & 69.5 \\
\hline & & & 島 & 地 & 域 & 62.0 & 40.8 & 30.8 & 45.7 & 7.2 & 13.5 \\
\hline \multirow{2}{*}{ 岡 } & \multirow{2}{*}{ 山 } & \multirow{2}{*}{ 県 } & 山 & 陽 & 側 & 36.6 & 27.3 & 22.0 & 13.3 & 41.4 & 59.4 \\
\hline & & & 島 & 地 & 域 & 89.6 & 81.3 & 9.1 & 16.9 & 1.3 & 1.8 \\
\hline \multirow{2}{*}{ 香 } & \multirow{2}{*}{$川$} & \multirow{2}{*}{ 県 } & 四 & 国 & 側 & 46.7 & 24.1 & 27.3 & 29.5 & 16.0 & 46.4 \\
\hline & & & 島 & 地 & 域 & 84.7 & 79.4 & 14.0 & 18.3 & 1.3 & 2.3 \\
\hline \multirow{2}{*}{$\begin{array}{l}\text { 広 } \\
\text { 岡 } \\
\text { 香 }\end{array}$} & \multirow{2}{*}{$\begin{array}{l}\text { 島 } \\
\text { 䏚 }\end{array}$} & \multirow{2}{*}{$\begin{array}{l}\text { 県 } \\
\text { 県 } \\
\text { 県 }\end{array}$} & 内 & 陸 & 側 & 34.5 & 20.3 & 33.1 & 21.1 & 32.4 & 58.6 \\
\hline & & & 島 & 地 & 域 & 72.7 & 57.8 & 22.7 & 33.6 & 4.6 & 8.6 \\
\hline
\end{tabular}

（備考）1. 国立公園協会調べによる.

2. 純自然海岸汀線, 半自然海岸丁線, 人工海岸门線の区別はつぎのとおりである.

(1) 純自然海浜地

樹林地, 砂浜, 崖が海面乞隣接している海岸線.

(2) 半自然海浜地

畑, 草地, 水田等の装策的上地利用执よび㟽業的土地利用に沿っている道路か海面と隣接している 海岸線.

(3) 人工海浜地

市街地，㙋立地，「抔地，工業用地およびそれらに沿っている道路が海面と隣接している海岸線.

否意識を高める結果上なっている。一部には行きすぎの 反対運動もあるが，やはり全般的には国民の意識が産業 開発よりも, おのおのの健康や, 自からが住む自然を美 しく保つこと定，より強く選択するようになっている。 そしてその動きがさらにより強くなってきつつむる。

昨年10月を契機に石油戦争が起り，順調にというより はきわめて急速に量的昖大をつづけてきたわが国経済む 一頓座をきたしている形であるが，てれは環境問題をも う一度よく振り返ってみるよい機会であると思わ机る。

そして1974年が, 本当に環境保全上有意義な年であるよ うにしたいと思う。そのために後述するような各施策を できるだけ効率的に実施したいと考えている。

\section{B. 水質污濁の現況}

昭和 42 年大気污染, 水質污濁, 悪臭, 騒音等の公害に 対する基本方針を律するあのとして公害対策基本法が制 定された。乙机をうけて水質污濁化関しては健康項目す な打ち水銀, カドミウム, 砒素, シアン等 8 項目および 生活環境項目すな打ち BOD または COD の有機污濁 物質, PH, SS, 大腸菌群, 油分など 6 項目の環境基準 が利水目的に応じて定めら机た。

さらに45年12月にこの環境基淮を守るための排水基準 が，水質污濁防止法により制定された。乙れまでは昭和 33年に定めら机た水質保全法により特定水域に排出する
咸水の規制屯行わ机ていたが，これは地域も限定さ机ま たその規制値む卯るやかなもので古ったから，全国的に 水質規制の網がかぶせられてからまだ 2 年半しか経過し ていない，乙の間全体としては工場事業場から排出され る污濁物質は急速に減少の方向を辿っているようであ る.過去約 20 年にわたって放出さ机てきた污濁物質，污 染物質により工業地带の地点先は污机，へドロが堆積し ているが少なくとも全般的には改善の方向がみうけられ る.

環境庁では毎年河川, 湖沼, 海域の測定を定期的に行 っているが，乙の結果によると有害物質すなわち健康項 目で環境基準值を超える割合は表3-(1) にみるごとく46 年度に打ける $0.6 \%$ から半減している。 てれは 45 年度の 1.4\%に比べると大幅な低下となっている. この中では シアン，カドミウム，鉛の各項目か環境基準を超える割 合が比較的高い。乙机は中小のメッキ工場や電池取扱事 業場, 製版工場によるものと思われる。高浱度の有害物 質を検出するのは特定の非鉄鉱山の下流を除いては都市 河川や，工業地带の水域が大部分である.

一方生活環境項目についてみると表3-(2)によるでとく 河川では環境基淮を超える割合が 4 6年度の $23.0 \%$ から $23.8 \%$ 若干上昇している. そしてとくに AA からC 類型のいわゆる魚が棲息するような奇麗な河川が前年よ 
表 347 年度公共用水域水質測定結果

（1）有害物質の環境基準值を超える場合

\begin{tabular}{|c|c|c|c|}
\hline 測定項目 & $\begin{array}{l}\mathrm{E}_{\text {調査対象 }} \\
\text { 検 体 数 }\end{array}$ & $\begin{array}{l}\text { 基準值を } \\
\mathrm{F} \text { 越え検 } \\
\text { 体数 }\end{array}$ & $\underset{(\%)}{\mathrm{F} / \mathrm{E} \text { 割合 }}$ \\
\hline シ ア ン & 22,223 & 113 & $0.5(1.2)$ \\
\hline アルキル水銀 & 10,968 & 0 & $0 \quad(0)$ \\
\hline 有機 リン & 12,004 & 0 & $0 \quad(0.2)$ \\
\hline カドミウム & 27,951 & 95 & $0.34(0.7)$ \\
\hline 鉛 & 27,067 & 181 & $0.7(1.4)$ \\
\hline クロム( 6 価) & 22,437 & 15 & $0.07(0.1)$ \\
\hline 七 & 21,991 & 64 & $0.29(0.4)$ \\
\hline 総 水 銀 & 22,727 & 8 & $0.04(0.3)$ \\
\hline 計 & 167,368 & 476 & $0.3(0.6)$ \\
\hline
\end{tabular}

（注）（1）括弧内は46年度の割合

(2) 測定地点 3,412

河川2,343 湖沼245 海域 824

（2）生活環境項目の環境基淮を超える場合（47年度）

a 河川 測定地点 1,436

\begin{tabular}{|c|c|c|c|}
\hline 類 型 & $\begin{array}{l}\mathrm{N}_{\text {調查対象 }} \\
\text { 検 体 数 }\end{array}$ & $\begin{array}{l}\text { 基準值を } \\
\mathrm{M} \text { 超える検 } \\
\text { 体数 }\end{array}$ & $\begin{array}{c}\mathrm{M} / \mathrm{N} \\
(46 \text { 年度) }\end{array}$ \\
\hline A A & 4,714 & 1,087 & $23.1(21.4)$ \\
\hline A & 50,067 & 12,159 & $24.3(22.2)$ \\
\hline B & 32,396 & 7,724 & $23.8(22.0)$ \\
\hline $\mathrm{C}$ & 13,014 & 2,708 & $20.8(16.9)$ \\
\hline $\mathrm{D}$ & 9,227 & 1,430 & $15.5(18.0)$ \\
\hline $\mathrm{E}$ & 11,618 & 3,720 & $32.0(35.2)$ \\
\hline 計 & 121,036 & 28,828 & $23.8(23.0)$ \\
\hline
\end{tabular}

b 湖沼 測定地点 229地点

\begin{tabular}{c|r|r|r}
\hline 類 & $\begin{array}{r}\text { 型調查対象 } \\
\text { 検 体 数 }\end{array}$ & $\begin{array}{r}\text { 基隻值を } \\
\text { 体数 }\end{array}$ & \multicolumn{1}{|c|}{$\begin{array}{c}\mathrm{M} / \mathrm{N} \\
\text { (46年度) }\end{array}$} \\
\hline $\mathrm{A} \mathrm{A}$ & 1,651 & 597 & $36.2(16.7)$ \\
$\mathrm{A}$ & 6,110 & 2,882 & $47.2(45.2)$ \\
$\mathrm{B}$ & 686 & 348 & $50.7(49.7)$ \\
$\mathrm{C}$ & 15 & 6 & $40 \quad(-)$ \\
\hline 計 & 8,462 & 3,833 & $45.3(43.9)$ \\
\hline
\end{tabular}

c 海域 測定地点 764

\begin{tabular}{c|r|r|r}
\hline \hline 類 型 & $\begin{array}{r}\text { 調査対象 } \\
\text { 検 体 数 }\end{array}$ & \multicolumn{1}{|c|}{$\begin{array}{c}\text { 基準值を } \\
\text { 体数 }\end{array}$} & \multicolumn{1}{|c}{$\begin{array}{c}\mathrm{M} / \mathrm{N} \\
(46 \text { 年度 }\end{array}$} \\
\hline $\mathrm{A}$ & 13,574 & 2,757 & $20.0(23.8)$ \\
$\mathrm{B}$ & 12,232 & 2,010 & $16.4(19.6)$ \\
$\mathrm{C}$ & 9,269 & 769 & $8.3(10.6)$ \\
\hline 計 & 35,075 & 5,536 & $15.8(17.8)$ \\
\hline
\end{tabular}

り污でれている. そして都市河川や，下流の今まで污れ ていたところの $\mathrm{D}$ およ゙ $\mathrm{E}$ 類型のところの基準オーバー 割合が減少している.しかし， D, E類型のとてろがよ くなったといっても基準を超える割合が平均で約 $1 / 4$ ああ るのでらるからまだまだ不十分であるし，日本全国の河 川に角がすむようにしようというわれわれの目標, すな わちC類型以上（BOD で $5 \mathrm{ppm}$ 以下）にするにはなお 一層の努力を要する状況である.

つぎに湖沼についてであるが，47年度の測定結果は誠 に憂慮すべき状態であったすすへての類型にわたって污 濁が進行している.とくにもっと屯水の清澄な $\mathrm{AA}$ 水 域 (COD $1 \mathrm{ppm}$ 以下) のところの污濁の進行がいちじ るしい.このととは河川についてもいえることであるが 観光開発, 宅地開発がこれら山奥にまで進み, その結果 生活排水が奇麗な川や湖に流れこみ, また宅地造成の結 果土砂が流入し環境基準をこえる結果を招来したものの ようである. 一般の公害が産業によるものと異なり，乙 れはわれわれ一般国民が加害者であり，また被害者とな っているのである. 湖のうちでは琵琶湖, 霞ケ浦, 諏訪 湖の大きなしかも重要なところの污濁が沿岸流域に深刻 な問題を投げかけている.

琵琶湖についてみると比較的水の奇麗な北湖, に限ら ず, 南湖とも近年污れが進んでいるが, わけても観光地 化している南湖がいちじるしい．乙のためこの水を上水 道源亡している京都, 大阪に大きな不安を惹きおこして いる. 表 4 によるごとく, アンモ二ア性窒素の検出回数 は年々増加している．この結果藻が異常発生し浄水場の スクリーンの目をつまらせたりし，水道水にかび臭さを 与えたりして一時取水に困難をきたしたという現象も起 こっている.

霞ケ浦については昨年異常渴水の影響むあり盖殖鯉が 大量に死んだ. そして沿岸からの生活, 畜産, 工業等の 排水により年々污濁指標の COD 值が上昇し, ところに よっては $10 \mathrm{ppm}$ (悪臭の限界) をてすところあ出てい る. 河川にしても, 湖沼にしても上水道, 工業用水の水 源となるような上流が活濁されればそれが下流におよぶ 
表 4 琵琶湖水質 (アンモニア性窒素) 調査

\begin{tabular}{c|c|c}
\hline \hline 年 度 & 北 湖 $*_{1}$ & 南 湖 $*_{2}$ \\
\hline 42 & 2 回 $(4 \%)$ & 21 回 $(28 \%)$ \\
43 & 1 回 $(2 \%)$ & 26 回 $(34 \%)$ \\
44 & 7 回 $(13 \%)$ & 29 回 $(38 \%)$ \\
45 & 14 回 $(25 \%)$ & 44 回 $(58 \%)$ \\
46 & 24 回(43\%) & 49 回(65\%) \\
\hline
\end{tabular}

（注） *1 北湖は28地点 2 回観測 56 測定中アンモニア性 窒素が $0.01 \mathrm{ppm}$ 以上の検出回数

*2 南湖は19地点 4 回観測76測定中アンモニア性 窒素が $0.01 \mathrm{ppm}$ 以上の検出回数 （水産環境基準 $\mathrm{N}$ 分として $0.1 \mathrm{ppm}$ )

のは自明の理である．污濁の原因を元から断つ意味で今 後はこれら河川の上流，湖沼の污濁対策を從来以上に真 けんになって取り上げなければならない。

一方海域の環境基準を超える割合は表 3-(2)- c による ごとく $\mathrm{A}, \mathrm{B}, \mathrm{C}$ の各類型の水域とあ改善されている. これは従来むっとも污濁のいちじるしかった工業地带の 地点の水質を改善するために工場，事業場に対する規制 を強化した結果である.とのととが前述の河川の D, E 類型水域の水質改善状況にもみられる。改善されたとい ってもC海域で $8 \%$ 基淮值オーバーがあり，また全体 としてあ16\%弱の基淮值を超過している割合があるから 昔の白砂青松の状態とは比較すべくもない。

昭和 47 年度から環境庁では太平洋ベルト地带のうちで あもっとも污濁のいちじるしいといわれる閉鎖水域すな わち瀬戸内海, 伊勢湾, 東京湾の水質の一斉調查を実施

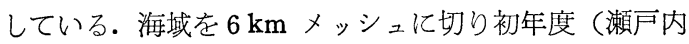
海は 47 年度, 他の 2 海域は 48 年度）は春, 夏, 秋, 冬の 4 回にわたり, 沿岸府県の協力を得て水質, プランク トン，底質調査を実施するととむに当海域に流入する COD の量を測定した. 瀬戸内海における第 $1 \sim 2$ 回の 調査結果は表 5 亿示すが, COD 值 $1 \mathrm{ppm}$ のととろが,

表 5 瀬戸内海水質污濁総合調査結果（47年） (CCD 值面積比率)

\begin{tabular}{l|c|c}
\hline \hline & $\begin{array}{c}\text { 第 1 回調查結果 } \\
(47.5 .22)\end{array}$ & $\begin{array}{c}\text { 第2 回調查結果 } \\
(47.8 .1)\end{array}$ \\
\hline $1.0 \mathrm{ppm}$ 以下 & $27.7 \%$ & $21.2 \%$ \\
$1.1 \sim 2.0 \mathrm{ppm}$ & 43.7 & 43.3 \\
$2.1 \sim 3.0 \mathrm{ppm}$ & 15.6 & 24.0 \\
$3.1 \mathrm{ppm}$ 以上 & 13.0 & 11.5 \\
\hline
\end{tabular}

約 $1 / 4$, しかなかった. 赤潮の発生しない外洋の水質が この值であり, 昔の瀬戸内海は大部分がこの值でカバー されていたと推定されるから, 昔と同じ水質の面積は随 分減ったものである．また $3 \mathrm{ppm}$ をてすところが $10 \%$ 以上ああった．との $3 \mathrm{ppm}$ を超す水域は環境 基準のC 類型に属し魚が棲みにくいところである．昭和30年以前 はタイ, サワラ, 車海老などの高級魚介類が豊富にしか あ容易に獲れたが, 現在はこれらの高級魚の水揚げが減 少し, カタクチイワシ, タチウオ, アナゴなどの中低級 魚の漁獲がふえ, 石油コンビナート近くでは油臭魚の発 生をみている. 赤潮の発生については表 6 亿みるとおり 昭和25〜30年までは発生個所む, 大阪湾の奥の一部, 岩 国地区などでく局地的で，件数む年 4 〜 件であったが 昭和 40 年ごろから件数が急激にふえるとともに発生区域 あ広域化し，47年は164件の発生をみた。なかであ 8 月 瀬戸内海東部に発生したものは，当水域における八マチ の大半を死なせたが，その数は 1,400 万尾, 被害額 71 億 円に扔よんだ。そしてその被害救済のために政府は天災 融資法を発動してれに当った。

表 6 赤潮発生状況（瀬戸内海）

\begin{tabular}{|c|c|c|}
\hline 昭和 $25 \sim 30$ 年 & $4 \sim 5$ 件 & $\begin{array}{l}\text { 局地的, 大阪湾の北部, 広島湾 } \\
\text { の奥の } 1 \text { 部, 岩国など }\end{array}$ \\
\hline 40 & 40 & \\
\hline 42 & 48 & ( 8$)$ \\
\hline 43 & 61 & (12) \\
\hline 44 & 67 & $\begin{array}{c}\text { （18）（）内は漁業被害を伴 } \\
\text { ったもの }\end{array}$ \\
\hline 45 & 79 & (35) \\
\hline 46 & 136 & (39) \\
\hline 47 & 164 & (23) \\
\hline 48 ( 1 ～10月 $)$ & 202 & (17) \\
\hline
\end{tabular}

なお38年は水質規制がより効果を発揮したことまた 雨が少なかったことなどの原因により赤潮の発生件数は ふえているが，長期間でしかも大規模な赤潮の発生も少 なく，大きな漁業被害が発生していないのは幸いなとと であった。

瀬戸内海は浅瀬が多く, 海岸線がながく, 海上交通の 要衝として，また消費地にあ近く工業立地に最適であり 工業開発の 拋点となってからは埋立工事が随所で行わ 机，山は削られるなどの自然破壊により，海の水屯濁っ た。海水の透明度む年々下がり, 昭和 30 年播磨灘で $9 \times$ 一トルあったものが，47年では 5 メートルを切ってしま っている.

つぎに東京湾であるが, 瀬戸内海と同様に昭和 30 年代 
前半までは多くの海水浴場があり，はぜ，きす釣りを楽 しむととができた。また潮干刚や篊立てが至るとてろで 行われていたのは記憶に新しい. しかし今日，乙の東京 湾で漁業が営まれているのは富津岬と横須賀の線を結ぶ 湾口以南になってしまった．海の水の污濁指標の COD 飞ついては, 横浜, 川崎, 東京, 千葉の地先では $4 \mathrm{ppm}$ 以上であり $10 \mathrm{ppm}$ を超すとてろが至るところに現われ ている. 昨年東京都, 神奈川，千葉の各県が実施した調 査結果の主なるものを列記すれば，

(1)東京湾は富栄養化され，湾奥で全密素 $2 \mathrm{ppm}$, 湾口 部で $0.5 \mathrm{ppm}, \mathrm{N} / \mathrm{P} 6 \sim 8$ と植物プランクトンの繁殖に 十分な条件となっている.

(口)東京湾流入する全窒素は $300 \mathrm{t} / \mathrm{D}$ ，全燐は $24 \mathrm{t} / \mathrm{D}$ であり東京の占める割合はいづれあ約 $55 \%$ である.

(湾内水中に現存する量は水量 $17.9 \mathrm{~km}^{3}$, 全窒素 $12,800 \mathrm{t}$, 全燐 $1,980 \mathrm{t}, \operatorname{COD} 31,200 \mathrm{t}$.

二東京湾に対する有機污濁負荷は外部（流入）負荷が TOD にして約 $2,000 t / D$ (流入 COD 負荷の酸化率を 5 割強とする）他方生物生産による内部負荷は TOD 1,300t/D となり内部負荷がその 4 割を占めている.

というように相当污濁が進んでいる.

多摩川では流域に造成された大規模の住宅団地からの 下水に工場排水が加わり, アユ, コイ, フナなどの魚類 の生育の場が上流に押し上げられ, また上水道の取水が 次第に困難になりつつある. 流域入口が急激に增えたて ともさることながら簡易浄化槽で水洗便所が使用できる ようになったが，その維持管理が旨く行われていないて 之. 屎尿処理場のあるとてろですその性能が十分働いて いないとと，洗濯および炊事に合成洗剂の使用が普及し これが，直接にまたは下水道を通じて間接に排出される ことなどの原因でこの多摩川のみならず都市河川の污濁 がいちじるしくなっている.

COD や BOD で表わされる有機污濁物質の他富栄 養化すなわち $\mathrm{N}$ 分 (窒素) および $\mathrm{P}$ 分 (燐)の增加が大き な問題になっている，乙れらの成分が家庭排水, 工場排 水, 畜産排水により湖沼に入り濃度が上がると, 植物プ ランクトンが殖え, さらに藻や莘などの水生植物が異常 繁茂するようになる. そして枯死再生を綝返し，次第に 湖水を污濁して行く. 前述した琵琶湖, 霞ヶ浦の他, 諏 訪湖, 帅島湖, 相模湖, 富士五湖など全国の湖はこの富 栄養化現象に悩まされている.中でも児島湖では窒素, 燐分による富栄盖化により“ほていあおい”が大繁茂し 水面が覆われたために漁業ができなくなるという事態さ え起っている．瀬戸内海，伊勢湾など閉鎖水域における 赤潮にしてもこの富栄盖化がプランクトンの異常発生の 基本原因となっているといわれる. 東京湾については前
述のようにすでに危険レベルを突破している。

これらの他に昨年大きな社会問題を提起したのが $\mathrm{PCB}$ と水銀による你污染である.PCBについては 47 年 環境庁は厚生省, 水産庁, 通産省, 運輸省, 建設省之之 むに日本全国における PCB 污染状況を調査した. この 結果厚生省が定めた魚介類の安全基淮である $3 \mathrm{ppm}$ を 超える魚が大分湾, 瀬戸内海の数水域, 敦賀湾など11水 域で発見された。 48 年に入りさらにての11水域を中心に 精密調査を実施したとてろ, 依然として 8 水域において 污染魚が発見された. 目下污染魚の監視, 堆積したへド 口の処理, 工場排水等の監視測定等を行っているとてろ である.

一方 48 年 5 月有明湾における第 3 水俣病患者発見の二 ニースは全国を社会不安におとし入れた。このため全般 的に魚の需要激減, 魚価の暴落が相次ぎ, 水銀使用工場 に対する漁民による補償要求が相次いだ．国ですつなぎ の緊急融資を措置するとともに PCB に準じた対策を立 案実施しているとてろである.

さらに海についてはタンカー等による廃油, 流出油が 海を污し，魚や海鳥を死なせ，ノリ，コンブ，ワカメな どの水産資源に大きな被害を与えている．乙のように日 本各地に扔いて水質污濁, 扔よびてれにより派生した魚 の污染が大きな問題になり，より進んだ，厳しい対策が またれている。

\section{C. 水質污濁対策}

昭和33年千葉県, 浦安の漁民による本州製紙江戸川工 場に対する漁業被害についての抗議事件発生を契機に, 水質保全法が制定され，污濁のいちじるしい特定水域の 水質規制が実施された．乙れとともに水質污濁関連工場 を設置する際の施設の届出義務等を盛込んだ工場排水法 屯定められた。しかしての水質保全法は適用される地域 あ限定され，さらに実際の規制むゆるいものであったか ら，実質的に排水規制が実施されたのは水質污濁防止法 が施行された昭和 46 年 6 月からといえる.また同年 7 月 公害行政を一元化する目的で環境庁が設置された。これ により日本全体が国の法律に基く排水規制の枠の中に入 るとととなった。

水質污濁防止法に上机ば人の健康に関係のある 8 項目 すなわち水銀, アルキル水銀, シアン, カドミウム, 有 機リン, 6 価クロム, 鉛, 七素について許容基準を示し また生活環境項目である BOD または COD, 油分, PH $\mathrm{SS}$, 大腸菌群などの項目について, 排水基準が定めら れ各水域の利水目的すなわち, 上水道, 工業用水, 自然 景観, 水浴場, 水産, などの使用条件に合致するように 設けられた環境基準を守るとととなっている。しかし工 場や都市住宅などの過密地区では国で定めた一率の排水 
基準より厳しい上乗せ基準を設定してその污れやすい， また污濁の激しい水域の水質を保全する仕組になってい る.

最近の調査によれば少くとも工場よりの污濁物質の排 水は峠をこし，とくに地方の大河川や一部の海域に扔い て水質改善のきざしがみえはじわたものがあるが，しか し, 東京, 大阪等の大都市周辺の河川や地点海域, 人口 增加傾向にある地方中心都市や宅地, 観光開発が進んで いる地区の水質污濁が依然としていちじるしい。乙のた めつぎの諸方策の推進がはかられ，またはこれから実施 されようとしている.

（1）監視体制の強化

現在の監視測定は都道府県および水質污濁防止法によ り都道府県の事務を権限委譲された政令指定都市（現在 横浜, 名古屋, 大阪, 神戸, 北九州市など20市）が, 公 共水域の水質が環境基準を遵守しているか否かの監視测 定（前揭表 3 参照）之污濁物質を排出する特定施設を有 する工場, 事業場の排出水の立入検查を実施しているが 最近とりまとめた 47 年度における立入検査の結果は表 7 のとおりである. 現在法に基く届出事業場すなわち特定

表 7 昭和 47 年度立入検査, 行政処分等件数

\begin{tabular}{|c|c|c|}
\hline \multirow{2}{*}{$\begin{array}{l}\text { 届出事業場数 } \\
\text { 規制対象事業場数 } \\
\text { (50t/D 以 } 1 \text { 上有 } \\
\text { 害物質排出) }\end{array}$} & 140,517 & \multirow{10}{*}{$\begin{array}{l}\text { 50t/D 以上 } 20,409 \\
50 \mathrm{t} / \mathrm{D} \text { 未満で有害 } \\
\text { 物質を排出する的 } \\
\text { の3, } 636\end{array}$} \\
\hline & 24,045 & \\
\hline 立入件数 & 43,099 & \\
\hline 寔＼cjkstart間 & 41,845 & \\
\hline 夜＼cjkstart間 & 1,254 & \\
\hline 行政処分件数 & 8,096 & \\
\hline 直 罰(告発中を含む) & 24 & \\
\hline 改善命令 & 1,426 & \\
\hline 一時停止 & 92 & \\
\hline 行政指導 & 6,554 & \\
\hline
\end{tabular}

施設を設置しているむのは約14万むるが，乙の中で一般 生活環境項目すなわち $\mathrm{BOD}$ または $\mathrm{COD}, \mathrm{PH}$, 油分, SS などの排水基準の適用をうける 1 日の平均排水量が $50 t / D$ 以上の事業場拉よび排水量が $50 t / D$ 未満で水銀, カドミウム, 鉛, シアンなどの有害物質（健康項目）を 排出する事業場を合せた数が，約 2 万 4 千むる. この 2 万 4 千の工場に対し 4 万 3 千回におよぶ立入検查を実施 したところ具合の悪いところが，約20\%の8千件もあっ た. そして中でも悪質な直罚, 操業の一時停止命令, 特
定施設等の改善命令などをうけたところが 1,500 件以上 に達している.上くに田子の浦地区に㧍ける, 製紙工場の 共同排水溝である岳南排水路の COD 值が, 昼間上り夜 間に高くなるので静岡県が抜打に立入検查したとてろ, 立入検查数 441 件に対し, 排水基準違反か 989 件, うち悪 質な17工場はきびしい処分をうけた。きわわて残念なが ら排水規制には人間の性善説はと机ないようである。

このような都道府県による立入検査の他に刑事事件上 してとくに悪質なむのを対象に警察当局, 海上保安庁も 違反の摘発につとめている. 規制対象工場数に比較して 都道府県の公害監視職員の数の不足, 分析能力の不足, など困難な面があるが，国でも公害担当者の增員，教育 研修, 機器整備のための補助, 水質污濁防止法に基く監 視測定権限委讓をさらに中位の都市にまで搪大するこょ 等による体制の整備を考虑しているところであろ。

（2）排水規制の強化と総量規制の導入

BOD または COD の排出寄与率は現在のとこ万産業 が $80 \%$ ，家庭排水が20\%とい水机ている. この産業排水

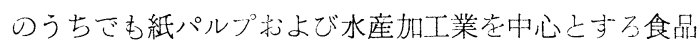
工業が圧倒的シエア恣占めている．昭和43年における調 査によ礼ば産業業種別 BOD 寄与率は表 8 にようご之く 紙パルプ食品工業の 2 業種で約 $3 / 4$ で古る。ついて化哭工

表 8 業種別水質污濁発生負荷量（工場・事業場）

total $\cdot$ BOD 負荷量 $14,000 \mathrm{t} / \mathrm{D}$ (他家庭排水約 $2,000 \mathrm{t} / \mathrm{D}$ )

\begin{tabular}{lrlcl} 
紙パルプ & 5,200 & ( & $37 \%$ & \\
食品 & 5,200 & ( & $37 \%$ & ) \\
化学工業 & 1,800 & ( & 13 & ) \\
繊維工業 & 1,200 & ( & 9 & ) \\
皮 & 200 & ( & 1.4 & ) \\
他 & 400 & ( & 2.9 & ) \\
\hline
\end{tabular}

業, 繊維工業, 皮革工業の順になっている. 現水質污濁 防止法に上机ば BOD の排水基準は日間平均 $120 \mathrm{ppm}$

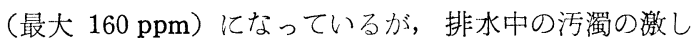
い紙パルプ，食品工業では直ちに国が定めた基準を守机 ないので法施行後 5 年間は, 上り軽い暫定基準（たとえ ばセミケミカルパルプおよび水産かん詰業では現在 300 ppm(最大 390ppm)）が適用されている。この暫定基淮 が昭和51年 6 月 23 日で発止されるので紙パルプ, 食品の 2 業種加ら排出される污渴負荷量は大幅に削減されるこ とになる，さらに現状の法体系では工場や都市住宅が密 集している過密地区ではその水域の環境基淮を守るため 国の一率基準よりきびしい上俥せ基準を各都道府県が設 定することになっており，現に43府県がこ机它実施して 
いる・したがって大部分の業種では国の基準が形䯚化し ている傾向がある．前述の暫定基準の廃止を契機にてれ ら国による一率基準の見直しが检討されるべきと考えて いる.

つぎに排水規制のための監視測定の強化および現行の 濃度規制の見直しが行われても, 河川, 湖沼, 内海等の 水質を早急に浄化するのは困難であると思わ机る，すな わち濃度規制では，

(1)新規参入事業者等から排出される污濁負荷量が規制 できない，また増設により排水量が増加した場合も同様 である、

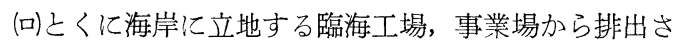
れる污濁物質が大量の冷却海水で稀勫さ机れば公共用水 域への負荷が増大する.

の理由により十分水質保全に刘応できない，むし排出 される排水の濃度が環境基準に近いほど厳しく規制され ているなら濃度規制が排出負荷量の抑制に働くかもしれ ないが，現状のように，環境基準の BOD または COD 值が 1 行の ppm 值であるのに対し, 排出水が 10〜120 〜300ppm では，都道府県で上乘基㔼を設置しても不十 分であり，一旦污れてしまった公共用水域の水を早急に 昔の姿にもどすととは困難である。このため污濁負荷量 の排出量在規制する総量規制の方式が，浮び上がってき たわけである.しかしこの総量規制導入には幾多の要解 決事項および検封事項がある。すなわち(㑩境容量の算 定, (口)規制項目の選出, (愩荷量の割当方法, 二濫視測 定方法等で㐫及。

(イ) 環境容量の算定

総量規制上いう言葉む，この環境容量という字句む世 閤で議論さ机るようになってからまだ日が浅く 3 年位な むのである。したがってまだ確たる定義すないが，一般 にi）自然の浄化能力すなわち拡散, 沈降, および微生 物または化学的な酸化分解（有機污濁物質の場合）によ り排出された污濁物質が自然界で消滅してしまう量の限 界上する考え方がある．乙の場合拡散抢よび沈降は最終 的汇消滅するわけでないからこれを省いて微生物および 化学的酒化分解される能力に限定する意見むある.

乙の場合, 浄化能力の範囲内に公共水域に排出される 污濁負荷量を㧕制すれば少く之もこの水域の水質の悪化 は予防できるこ上になる。しかしその量に限定して水質 規制を行う限りは水質の改善はのぞめないことになる. またこの考え方で行く上，自然界において酸化分解され ない重金鼠（水銀，カドミウム，鉙，七素など）は環境 容量上いう莯が馴染まないから理論的には当然総量規 制の封象上はなり得ないこ上になる。こ杂に対して ii) 人間の利水目的に対応する水質にするための許容排出負
荷量を環境容量とする考え方もでてくる. 当該水域の水 質が海の場合は外洋之同じ位に奇麗な水域ではｉ）之 ii）の量は同一になると考えられる。しかし現に污れて いるととろをよりよくする場合はその水域の環境容量は i ）とii）では後者が小さいはずである．またこてでど れ位の期間に水質をよくするかという時間のフアクター が環境容量に大きく影響する。いずれにしてもこの環境 容量を算出するには一定水域について，污濁負荷量の排 水量之, 当水域水質の経年変化の関係をみないと算定で きない，またその一定水域とはどの範囲にするかの議論 も出てくるが，たとえば瀬戸内海全体とする場合，また は分割して大阪湾, 厇島湾, 徳山湾などの水域を考える やり方がある。しかしながら現在信頼しうるに足る流入 負荷量上当該水域の水質のデータがほとんどない状態で ある。このため環境庁では47年度から瀬戸内海で，また 48年度から, これに加えて伊勢湾, 東京湾でこのための 調査を実施し，今後共継続して有機污濁物による環境容 量をできるだけ早く算出しようとしている，昔の海は， 河は奇麗だったといってもその数字的裏付けがまったく といってよい位ない.一般に観念としてわれわれの頭の 中にのてっているだけである.したがって今後はての污 濁指標を数值化して環境容量の解明に当らなければなら ないと考えている。

\section{(口) 規制項目の潠出}

前述したように自然界に招ける酸化分解等により，有 害なものが無害になるものに許容される排出物質のみに 限定するとすれば,現在用いられているBODまたはCOD で表わされる有機污濁物が規制項目になる。しかし富栄 盖化成分である䇪素 (N分) や燐(P)むなんらかの形で 無害になり公共用水から排除されるとすればとの項目に あ当然環境容量が算出され総量規制の対象となりうるし また対象としなければならない．太平洋や外洋を排出す る水量に対し無限の包容力を持つあのとすれば，たとえ 人間の健康に有害な水銀, カドミウム,などの有害なもで のむとの中に稀釈され机ば浄化されたとととなるからと のときは外洋への拡散がそれ自身環境容量算定の根拠之 なる。しかしてれらの有害物は原則として系外に排出せ ず回収廃棄処理するか，再利用するべきであろう．との ようにいろいろな考え方があるが，まずもっとも一般的 な污濁物質としての有機物をまずとり上げ, 後に必要に 忘じてその他の項目を採用して行くことを考えている.

\section{(少) 負荷量の割当方法}

環境容量が算定される之その量を流域に 所在する工 場, 事業場に割当ることになる.このとき本来の総量規制 の立前からいえば, 水域により環境容量はちがうはずで あるから流域が違えば割当をうける負荷量も当然ちがっ 
てくる．こてでこの考え方にたてば日本全国水域により 規制の强弱がちがうから，いわゆる立地規制および工場 再配置の考え方がこの中に導入されるととになる．また 環境容量自体は既存の排出源加らの污濁負荷量之当該水 域の水質の関係から算出され，しかもその水質をよくし ようとするわけであるから新規参入の余地がないととと なる.乙れをどうするかが大きな問題である.しかし新 規参入をまったく排除するのも実際問題としてとれない から, 許容污濁負荷量全部を既存の工場に割当てるので なく、より条件を厳しくして幾分かは新規参入者にも割 当すべきであろう.また水域によって生産量または生産 金額当りの割当負荷量(負荷量原単位)がいちじるしく異 るのも現実的でないから，国としてもある一定水準のシ ビルミニマムを考慮し, 高污濁地域以外の地区にての割 当負荷量を適用すべきであると考える. 現在環境庁では 第一に瀬戸内海, 伊勢湾, 東京湾, 琵琶湖, 霞ケ浦の污濁 のいちじるしいととろに総量規制を実施すべく調査を実 施中であるが，その他の地区にはいわゆるこのシビルミ ニマム的な負荷量規制を行うことになるかすしれない。

$\Leftrightarrow$ 監視測定方法

污濁負荷量は排水量と水質の積で算出される. した がって時々刻々排出量, 抢よび氷質の変化することが 多いから，乙れを打のおの連続的汇測定する必要があ る. しかし現在有機污濁物の指標として採用している BOD および COD はての連続測定になじまない.すな わち BOD は結果が出るまで 5 日間, COD す約 1 時間 要する.さらに両項目とも割合に誤差が多い。とのため TOD (Total. Oxygen. Demand) TOC (Total. Organic. Carbon) が注目されている. 双方とも瞬間的に連 続測定が可能であるので総量規制の項目としては好都合 である・しかしての考えが導入されてから日が浅く目下 機器あ改良途中にあるとと, 一台当りの機器が 4 〜 500 万円と高価であること・したがって十分に普及していな いなどの問題点があるが，てれが解決されれば採用項目 として適当であると考えている. とくに TOD は TOC に比較して有機炭素以外の污濁物質も測定されるからよ り有利ではなからうか.しかしいずれ伅しても排水量の 少ない中小企業に TOD むしくは TOC と水量計を連 動させて污濁負荷量の連続測定を義務づけるのは適当で ないからそのときはコンポジットサンプラー（排水量に 忘じてサンプル量を調整できるあの）を用い断続的に水 質をはからせることにより対応すべきであろう.

以上総量規制の採用に当っての要解決, 検討事項は種 タあるが，できるだけて机らの問題点を解決し， $2 \sim 3$ 年後にはなんらかの形で法令に基く採用にふみきりたい と考えている.

\section{（3）下水道の整備}

河川, 湖沼, 海域等公共用水域化排出される有機污濁 物質の約 $20 \%$ は家庭からの排水である.さらに水質污濁 防止法の規制の対象とならない中小企業ないしは零細町 工場の排水は下水道による処理にまたなりればならな い. とくに大都市河川の污濁は家庭下水の寄与率が高い から重点的に下水道の整備をはかる必要がある.昨今は 住宅地開発や観光開発により從来まで奇麗だった中, 上 流の河川や山奥の湖も污れるようになったので都市部の みならずとれら農山村地带の下水道の整備が急がれる. しかるにわが国の下水道の整備率は昭和 47 年で対人口比 19\%，都市部でさえ（整備面積/市街地面積）25\%にす ぎない，乙れは欧米諸国の70～90\%（都市部ではほとん ど100\%）と比較すべくもない．以前は土地還元されて いた屎尿が，簡易浄化槽や，不完全な尿尿処理施設を通 じて公共用水域に放出されている. また所得水準の向上 とともに 1 人当りの使用水量も急激に増加しておりてれ に基く雑廃水（台所廃水）による負荷の增大をむたらし ている.

産業廃水のほうは濃度規制の強化, 総量規制の導入に よりその負荷量が抑えら机る傾向にあるが，乙机ら家庭 排水汪上万公共用水域の活濁を抑え, これを浄化するに は一日も早い下水道の整備が必要である。建設省では現 在進行中の第 3 次下水道整備 5 力年計画（昭和 46 年 50 年度までで都市部における普及率を $50 \%$ にする）を改定 し49年度から新たに第 4 次 5 力年計画を発足させ 8.5 兆 冈の巨額な投資により人口普及率 $50 \%$ に上げうとして いる. そして長期的には昭和 60 年頃までに対人口普及率 を90\%（都市部は100\%）にする長期目標を設定してい る. 現在の下水道は活性污泥法により BOD $200 \mathrm{ppm}$ 前 後の家庭廃水を 20 ～ $30 \mathrm{ppm}$ に落しているが，乙れをよ り高級処理して $10 \mathrm{ppm}$ 以下にするととあに，富栄養化 の成分である窒素, 燐分む処理する予定であるから, そ の成果が一日も早く表われることを期待したい。そして 欧米なみの，より衛生的なしかもよい環境をわ机わ机が 持ちたいものである.

（4）瀬戸内海環境保全臨時措置法, その他.

瀬戸内海は古来, 白砂青松の景勝地としてまた漁業資 源の豊庫として，われわ机日本人に天然の恵みをむたら してきた。 しかるに昭和 30 年以降の工業化の進展ととも に海岸は埋立てら机, 水は濁り, 魚む有害物質に污染さ れるようになってきた。乙の瀬戸内海を昔の海に戻すべ くこの度, 超党派による議員立法の形で臨時措置法が提 案され昨年11月 2 日に施行された。この法案には(イ瀬戸 内海の環境保全上有効な施策実施を推進するため, 水質 保全, 自然景観の保全等に関し基本となるべき計画を策 
定するとと, (口)沿岸流域に排出される産業排水中の COD の量を 3 力年で 47 年当時の $1 / 2$ に減少させるとと. (促来届出でよかった産業排水に係る特定施設の設置お よび許可制を導入したとと。(埋立については瀬戸内海 の特殊性につき十分配慮するとと.などの項目が盛り込 まれている．環境庁でもこの法律を円滑に実施するた め, 瀬戸内海対策室を発足させとの事務処理に当ってい る. この法律は時限立法で 3 力年で効力を失うが，それ までに瀬戸内海が現在より数段奇麗になり, 少しでも苩 の姿に立ちかえることを願っているところである。

以上の他，法律による規制対象事業場の拡大，すなわ ち現在水質污濁防止法による規制の対象外となっている 旅館, 病院, 試験研究所等に規制をかけるとと. 富栄養 化の原因である窒素, 燐, や合成洗剂の主成分である ABS などを規制項目とすることなどを検討中である. さらにタンカーによる油濁について海洋污染防止法のき びしい適用と, 廃油処理施設の設置およびその利用の義 務付けあ必要である. とくに廃油処理施設はすでに相当
数設置されているが，その場所まで行って処理するのに 日数がかかりまた処理費用を要するため，利用率は20〜 30\%と低調である. 海洋から油活染を防ぐには，航行中 のタンカーの事故予防防止之事故時の緊急処理はもちろ ん大事であるが，海洋污染の最大の原因である廃油の たれ流しは速かに排除されなければならない.さらに一 進歩めて水質污濁が太平洋ベルト地带においてもっとも いちじるしいからその根本的解决をはかるためには瀬戸 内海沿岸のみならず，当太平洋岸における工場立地の制 限，埋立規制にまで遡及しなければならないだろう。

いずれにしても今まで述べたいろいろな水質規制方策 や公共用水の净化策を実のあるものにするには国民一人 一人が環境を守るという心構えが大事である・日本人は とかく自分のところは奇麗にするが，一歩外に出ると 駅，道路，公園を問わずごみを捨てたり，公共施設を破 壊したり，草木を折ったりすることに平気である．この 心の成めとそがもっとも必要なととではないだろうか.

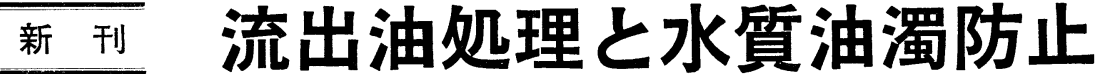

\section{神戸商船大学教授 工博 近 藤 五 郎 著}

A 5 版 210頁 定価 1,800円 送料 200円

著者は10数年来この海洋污染防止技術について，種々の面からたゆまぬ努力を続け てこられた権威者であり，今回，多年の成果をとりまとめ環境技術研究会から刊行の 選びに至った次第です。

海洋の污染を防止するために，日常行なわなければならない含油廃水の処理から， 不幸にして流出した事後の緊急処理にいたるまでの各種の問題について，多くの論文 を集大成されたこの本は関連科学，技術者にとって絶好の参考書であると信じます。

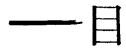

〔I 総 説

(1) 流出油処理について

（2）海水油濁の防止技術

（3）水質の油濁防止技術について

（4）海洋油濁とその防止技術

(5) 流出油処理技術の現状之問題点

\section{〔II] 流出油の捕集}

(1) 浮上油の捕集法に関する研究

(2) 流出油捕集機の試作

(3) 流出油処理用資材について

(4) 流出油処理に扣ける油吸着材のシ ステム化

\section{〔III〕流出油の分散}

(1) 流出油処理剂の試験報告(1)

(2) 流出油処理刻の試験報告(2)

(3) 流出油処理剤の試験報告(3)

(4) 流出油処理剂の乳化分散能測定に ついて

(5) 高性能低毒性流出油処理剤の開発

(6) 流出油分散処理の可否について

\section{次一}

(7) About the Propriety of Dispersing Method for Spill on Sea

〔IV] 流出油の焼却

(1) 流出油の焼却処理法の研究

[V] 流出油の変化

(1) 流出油の経時変化に関する研究(1)

(2) 流出油の経時変化に関する研究(2)

(3) 廃油ボールについて

〔VI〕分析または測定

(1) 油層厚測定機の試作

(2) 海上流出油の油層厚測定試験

(3) 廃水中の油分の測定

(4) 含油廃水中の油分測定上の問題点

〔VII) 船 舶 廃 水

(1) 船舶廃水処理施設の現状と問題点

(2) 気泡会合によるダーティーバラス 卜の処理

（3）気泡会合による油水分離

（付）関係特許 